\title{
Implementation of Surakarta Regional Governtment Policy about Difable Labors' Power in Surakarta, Indonesia
}

\author{
Rizal Habi Nugroho*; I Gusti Ayu Ketut; Lego Karjoko \\ Faculty of Law, Universitas Sebelas Maret, Indonesia \\ Email: rizalhabi30@gmail.com
}

http://dx.doi.org/10.18415/ijmmu.v5i3.389

\begin{abstract}
Generally, people with disability has the same right to other people. However, in the reality of social living, it is often found they are treated discriminatively. Therefore, law number 13 Year 2003, law number 8 Year 2016, and law number 4 Year 1997 are created accordingly toward regional regulation Number 2 Year 2008 as the policy of Surakarta government in protecting them. This study has purpose to find out and analyze the implementation of Law Number 2 Year 2008, to analyze the implementation of right protection of labors with disability, and to understand and analyze the hindrance in its implementation. The study is done through empirical juridical approach using analytic descriptive. The study results some findings. First, the right of labors with disability has been regulated by Article 45 until 54 of Law of People with Disability Number 08 Year 2016. Second, Article 53 in the Law also states that Regional Government, State-owned Enterprises, Regional-owned Entprise are obliged to employ at least $2 \%$. Beside that, private enterprises is also obliged to employ labors with disability at least $1 \%$ from the whole labor's numbers. Third, based on the supervision of the implementation of Regional Regulation Number 2. Year 2008, about administration sanction from the mayor toward any company breaking the reuirements, are not yet realized.
\end{abstract}

Keywords: Employment; Disability; Surakarta Regional Government Policy

\section{Introduction}

The Republic of Indonesia highly appreciates human rights. The essential elements of the Republic of Indonesia's 1945 Consitution admits and manages the conceptions of human rights. These conceptions are seen as attached instuments on the essence and existence of human as God's creatures and as gifts to respect, appreciate, and fulfill by the country. The emerging consequences are constitutional obligation of the country to respect, appreciate, and fulfill every right of Indonesian without any discrimination. Every human right constitutes to basic obligation and responsibility to respect other right and becomes the task of Government to respect, protect, keep, and improve (Human Right.,1999).

The government of Indonesia, based on the substances of the Consitution, has commitment to appreciate every Indonesian's right. It is seen in Article 28 of the Consitution stating many regulation about the basic rights to gain by every human. Some of the rights are regulated in the Article are: i) right 
to live; ii) right to accept equal treatment in justification and law; iii) right to get equal chance to seek jobs and education; iv) right to get living both phyical and spiritual and facility and special treatment if needed.

The rights are guaranted constitutionally and intended to all Indonesian without any execption, included those having physical and mental disability. Based on Martin Kock stating that:

"The purpose of the Behindertengleichstellungsgesetz (and supplementary changes to other laws) is to implement equal rights for disabled people in public and private areas and enable them to live life with as little outside help as possible. The Act includes, inter alia, provisions regarding:

a) a ban on the discrimination of disabled people by public authorities;

b) provisions responding to the special needs of disabled women ("gender mainstreaming");

c) the obligation of the Federal Government to barrier-free buildings, administrative procedures and access to information technology;

d) barrier-free environments as regards elections; and barrier-free access to restaurants and means of transportation (Martin Kock., 2002).

In Article 2 of Convention on the Rights of Person with Disabilities, who is included to be people with disabilities are those having physical, mental, intellectual, and sensoric suffers for longer term. Beside in Indonesia, the term diability is also used internationally (Convention Legalization of Difable., 2011). People with disabilities are still discriminated in terms of their rights. Based on the coordinator of Diability Rights Australia Indonesia Partnership for Justice, Cucu Saida, says the justice for every person with disabilities is still ignored. Even, those people feel the law still not giving them proper protection.

One of the problems of those people is the limited access to get job or to enroll school. This condition makes them becoming fragile toward poverty (Andi Ahmad Yani., 2011). In educational world, many of them are having difficulties to gain access into education because of their disabilities. This condition makes them discriminated and being difficult to get equal right in education.

It also happens in employment. People with disabilities are having difficulties to get job because of negative stigma growing on society. The problems of employment in Indonesia from years to year are faced on one higher sided growth of employment, meanwhile still have limitation on educational level and sufficient skills as well as working opportunities.

The government struggles to decrease unemployment level and to improve living quality of the labors in Indonesia. Law Number 13 Year 2003 about Employment arranges the problem of labors' employement. The rights and protections toward labors are regulated in the regulation of Indonesian Employment is one thing to struggle in order to improve the labors' dignity and humanity. The protection is purposed to guarantee the basic rights by paying attention on international and national enterprise world advancement (F.Wisanu., 2011).

Based on the law about Employment, it is frequently stated after Article 1 Number 2 of the Law about Employment, the term Employment has general definition, that is every one having capability to do their job to produce goods or services. Through the role done by Surakarta Regional Government in the regulation of Surakarta Mayor Number 9 year 2013, in this case the Employment and Industry Agency of Surakarta, provides equal job vacancies to people with disabilities. 
According to Article 27 of the regulation of the Mayor, the agency functioning in employment field helps labors with disabilities to companies or regional-owned enterprises. This support is realized by Law Number 4 Year 1997 about People with disabilities. In line with the content of Article 13 of Law, Number 4 Year 1997 about People with disabilities that "Every person with disabilities has equal chance to get job based on types and their disability level".

The regulation for enterprises obliged to employ people with disabilities is also stated in Article 28 of Regional Regulation Number 43 Year 1998 about the Efforts to Improve Social Prosperity for People with Disabilities stating that employer must employ at least 1 person with disability whose requirements fit to the position or qualification as labor in the company for each 100 labors employed in the company. This regulation is not only to protect but to be obyed. Private enterprises must employ $1 \%$ of people with disability. This obligation is in line with Law Number 8 Year 2016 about people with disabilities. To supervise and control private enterprises which have employed the difable people, Law Number 7 Year 1981 about Employment Reporting Obligation is existed.

\section{Methodology}

The method of the rsearch is empirical juridical approach. It is an approach to analyze various regulation of laws containing the regulation related to law protection toward quota fulfillment of $1 \%$ difable labors in Surakarta and also the impacts, effects, and hindrances in the implementation of the law. Meanwhile, empirical approach is not only merely used as an instrument of normative law only, however it is seen as society behaviors, always interacting and connecting in every aspects of society, such as politics, economy, social and cultures (Suharsimi Arikunto., 1992).

\section{The Implementation of the Policy to Overcome Difable People Employment Problems Obligated based on Law Number 8 Year 2016}

The principle used to control the avaibility of difable labor in private enterprises is regulated in Law Number 7 Year 1981 about Employment Reporting Obligation. The law also regulates the consequences for private enterprises which does not implement it.

The Chief of Agency of Interest and Talent Development of Difable Children Educaiton Foundation (YPAC) Solo, Sugian Noor, adds that although in Solo there is Regional regulation related to the problem, there are still some enterprises not employing difable people. He explains, the regulation does not fully support the difable people (Sugian Noor., 2018).

\section{The Implementation of Regional Regulation Number 2 Year 2008}

The implementation of the regulation meant in this research is related to job availability for difable people by the regional government of Surakarta.

\section{a. Socialization}

The initial process of a policy to implement is socializing process. It is purposed to have the society as the target recognizing the purpose and the point of the policy. 


\section{b. Implementation}

The regulation started to implement in June 10, 2008. However, the implementation is not completed by the regulation to act. Therefore, it is really important to have action or programs for the regulation to implement.

\section{c. Guiding and Supervising}

There are some programs such as on the job training for three months in an institution, training, giving equal facility to follow by difable people.

2. The Implementation of the Regulation to Protect Difable Labors According to Law Number 4 Year 1997 based on the Regional Regulation Number 2 Year 2008

\section{a. The Protection for the Labors}

According to Law Number 13 Year 2003 about employment, Article 28 of Employment Law, states that employer must employ at least 1 (one) difable person having requirement for the vacant position and qualification of the job for each 100 (one hundred) labors. The implementation of $1 \%$ quota is regulated in Article 14 Law Number 4 Year 1997.

\section{b. Lack of Socialization of Article 14 Law Number 4 Year 1997}

The lack of socialization of the regulation causes many employers still do not understand and comprehend the content of the law. Therefore, it is understandable when they still have not fulfilled the quota because of their less recognition about the law regulating difable labor quota fulfillment.

\section{c. Weak Supervision}

The supervision toward the regulation implementation is still weak. It is proved by less information broadcasted by mass media about any employer being punished because he does not fulfill the quota regulation. In fact, in the reality, many of them have not implemented the regulation about the quota.

Based on the Law Number 13 Year 2003 about employment, it is stated that supervision is done by supervisor of employment. It is in line with Article 176 stating that the supervision is done by employment supervising officers whose competences and is independent to guarantee the implementation of the law.

The requirements to regulate the problems of supervising difable labor employment are technically followed up by the Decree of Minister of Indonesian Republic Employment Number: Kep205/MEN/1999 about Job and Training Employment of Difable Labors. In Article 12, it is said: "The supervision toward the decree is done by Supervisors of Employment based on the requirement by current law". Beside that, Article 4 paragraph 1 of the Decree Number: Kep-205/MEN/1999, I said "for every 100 labors, the employer must employ at leat 1 difable labor based on the requirement and job qualification. It is strongly emphasized that the one having authority to supervise the implementation is supervisors of employment. 


\section{The Hindrance of the Law Implementation Toward Difable Employess in Surakarta}

Difable people must get equal service employement, especially their rights toward getting appropriate job fulfillment and to arrange policy and to run various programs or activities to create accessible and inclusive society for all, especially for difable labors of Indonesia.

According to Law Number 4 Year 1997 about difable, it has been emphasized that those people have equal rights to get better and appropriate job and to get equal treatment without any discrimination from Indonesian enterprises. However, the number of those enterprises employing difable people can be said lower. In fact, based on the regulation, every enterprise must at least employ at least one difable person having requirement and qualification of the vacant job for each 100 labors.

In Law Number 082016 about right of having job upon difable person is stated in article 11 stating the difable has right to get job held by both government or private without any discrimination and has right to get equal payment in every kind of job and has equal responsibility plus not being stopped from the job due to his disability.

In government environment, the right for difable person is regulated in article 45 until 54 of difable Law number 08 Year 2016, even in article 53. The Law consists the obligation of the government, regional government, state-owned enterpreises, and regional-owned enterprises to employ at least $2 \%$ difable person, meanwhile $1 \%$ for private enterprises.

Any private enterprise employs a certain number of difable labors must be given insentives by the government as stated in article 54 (Rerey Akbar., 2017).

The hindrance of implementing $1 \%$ difable labors is cuased by some factors below:

\section{1) Aspects of Disability, Mentalilty, and Low Skill Quality Behaved by Difable Person}

There is a negative stigma upon difable person seen from their disabilities and weanknesses. The difable person is believed to be weak person; cannot work; and cannot do anything which lately cannot be helped to be more independent and potential person. The difable person is considered only to rely others' compassion, such as asking for donation, beggars, and etc.

The weaknesses upon difable person are such as easy to give up psychology social mental, easy to isolate himself, lower mobility, and other aspects of weaknesse making them difficult to be employed in any enterprises. This bad mentality is reflected on those difable persons taking advantages upon themselves to get personal profits by exploiting their weaknesses to be beggar or etc. These factors will trigger negative stigma from employers whom actually should have cared about them.

Low skill quality of difable person also influences the users of labors' judgment. Their skill level will affect toward productivity. People with higher skill and professionality will produce qualified good or service in huge number. It is in contrast the lower skill people will have difficulties to meet the company requirements in producing. There will be working volume differences between difable and normal employess. It can be seen from aspects of working volume, working speed, working condition, and the condition of difable person. It means that the difable person is not employed in reckless positions, however in special place, the easy one.

There are some weaknesses and lacks of difable person influencing employers to not employ them. With various reason, such as no job vacancy offered yet, or insufficient qualification toward the job 
vacancy availability because the qualification of labors in various aspects such as skills and education are important.

Meanwhile, in this globalization era, to get market share in industrial field needs skillful, discipline, and productie labors. Their high skill are the most important to contribute toward productivity improvement. So productivity target of the company can be achieved by the labors in their job. Because of the existence of difable person, it causes the quota regulation is not fulfilled. So this case is special in nature and needs to get treatment and regulation exclusively by law regulation.

\section{2) Less Accessibility in Enterprises}

Accessibility is easy access provisions provided for difable person to create equal chance in every aspects in life and living. For the difable people to interact with working environment, specific facilities for them must be provided to make them having mobility independently. The facilities in enterprises whose been having accessibility will ease their mobility. As for example, the use of special door, lift, and toilet for difable people must be provided.

From the findings can be conluded generally Surakarta Regional Regulation Number 2 Year 2008 about equality upon difable person has been implemented by Social, Employment, and Industrial agencies of Surakarta until socializing stage although still on going. The process of the law implementation is divided into three steps:

\section{The Policy of Surakarta Government to Overcome Employment of Difable People}

The requirements in private enterprises to have at least $1 \%$ difable labors from whole labors is stated in Law Number 8 Year 2016.

The law states in article 11 stating difable person having equal rights to get job held by both government or private enterprises without any discrimination and to get equal payment in the type of job and responsibility as well as not being stopped from the job due to their disabilities. The rights of difable people in Employment is stated in article 45 until 54 of law. Even in article 53 in the law, government, regional government, state-owned and regional-owned enterprises must employ at least $2 \%$ difable labors. Meanwhile, for private enterprise must employ at least $1 \%$ difable labors. For the enterpises employed them, the government will give instentives as stated in article 54.

2. The Implementation of Surakarta Regional Regulation about Difable Labors' Protection According to Law Number 4 Year 1997 with the Implementation of Regional Regulation Number 2 Year 2008

Based on the supervision results of the regulation implementation, it has sanction in the form of administration sanction given by Mayor for the enterprises breaking the regulation, has not been realized. It is proven from the existence of sanction which has not been found. There is no real consequence implemented even the society has not recognized the kind of administration sanction given by the Mayor.

\section{Conclusion}

The policy of Surakarta Regional Government to overcome difable labor problem is stated in article 45 until 54 of difable Law Number 08 Year 2016. Specifically, in article 53 is stated that government, regional government, state-owned and regional-owned enterprises must employ at least $2 \%$ 
labors. Private enterprises must employ at least $1 \%$ difable labors. Based on the supervision result of regional regulation number 2 Year 2008, the sanctions are administration from Mayor toward enterprises breaking the regulation is not fully implemented.

\section{Acknowledgment}

The researcher says thank you to Faculty of Law of Sebelas Maret University Surakarta as the place for him to write this journal. Thank you to all lecturers for their guidance.

\section{References}

F Winanu. (2006). Administrasi Gaji Dan Upah, (Yogyakarta: Pustaka Widyatama).

Martin Kock. "Disability Law in Germany: An Overview of Employment, Education an Access Rights", German, I July 2001-1 May 2002: 5(11).

Suharsimi Arikunto. (1992). Prosedur Penelitian. Cetakan Kedelapan Jakarta: PT. Rineka Cipta.

Undang-undang No 19 Tahun 2011 Tentang Pengesahan Konvensi Hak-hak Penyandang Disabilitas pasal 2.

Pasal 69 Undang-undang No 39 Tahun 1999 Tentang Hak Asasi Manusia Anonim. http://www. hukumonline.com/berita/baca/lt505bcf1f79b82/keadilan-kaum-disabilitas-masih-terlupakan. Diakses Pada Tanggal 11 Februari 2017.

Andi Ahmad Yani. http://makassar.tribunnews.com/2013/10/23/kelalaian-negara-memenuhi-hak-wargadifabel. Diakses Pada Tanggal 10 Februari 2017.

Rerey Akbar. http://renaldyakbar.wordpress.com/2012/10/18/. Diakses Pada Tanggal 11 Februari 2017.

\section{Copyrights}

Copyright for this article is retained by the author(s), with first publication rights granted to the journal.

This is an open-access article distributed under the terms and conditions of the Creative Commons Attribution license (http://creativecommons.org/licenses/by/4.0/). 